\title{
Equipping the poorest of the poor to become agents of community transformation: A case study of milk as a catalyst in Burundi
}

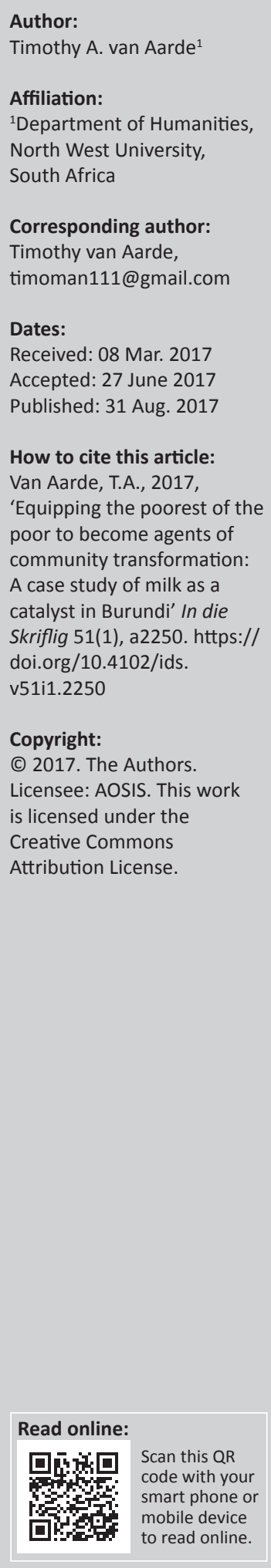

Community transformation has cultural, political and religious dimensions. In the case of Burundi, it is ranked 188/188 on the scale of the world's poorest countries. The poor in Burundi have a fatalistic attitude towards poverty as a result of the unstable political climate, corruption and a climate of suspicion. The poor are cynical and have no hopeful future expectations. The resourcefulness of the poor having been muted. The Christian church of Burundi has developed a culture of dependency. The role of the church in the West has been limited to lifting the poor out of abject poverty. A creative use of available resources and the participation of the poor through the recognition of their own resourcefulness and stewardship is a sustainable approach to the alleviation of poverty. Newfrontiers churches have developed the approach of equipping the poor as a mission's strategy to participate in the missio Dei. The majority of churches and non-governmental organisations who endeavour to alleviate poverty in Burundi have, what can be termed, a 'dependency virus' or 'dependency crisis' and are victims caught in the 'dependency trap', that is, they create a culture of dependency through their provision. The loss of dignity that follows, transform the community into a slave of the beneficiary system in which poverty is conceived as a lack of things rather than a mind-set born from help given by the beneficiary without the consent of the poor.

\section{Introduction}

A distinctively unique missional approach is advocated by Evariste Ndayirukiye in which the sole aim is more than the realisation of the resource fullness of the poor. It is to lift them into fully functioning members of the body of Christ and to have them involved in effective mission. In this approach the poor are empowered to become fully participating members of the church and in the missio Dei. It is an approach that lifts people from requiring on-going support to becoming contributors to their local community - a community to which a reformed perspective on communal transformation as participators in the mission of the church and the missio Dei anchors the approach foundationally and biblically. Mission is directed at a specific context, ethnic or social group. This article addresses missions towards the social group located at the outermost fringes of society - the often abrogated 'poorest of the poor'. It is the poorest of the poor who are caught in the cycle of violence and war. 'Some 80 percent of the wars today happen in the world's twenty poorest countries' (Schreiter 2010:20). The poorest of the poor are 'those whose hopes have been dashed, become the pool of people who can be recruited to violence' (Schreiter 2010:24). The poor 'find themselves displaced, disorientated, disappointed and dispossessed' (Schreiter 2010:24). Mission directed at the poorest of the poor is about empowering and developing their capacity. The poorest of the poor have no confidence and competence in decision making, and no confidence to act on their choices (cf. Roy \& Hartigen 2008:67). The poor need to be helped to develop themselves. It is the poor who are able to find the best and lasting solution to their own situation of poverty. Mission and intervention with 'the poorest of the poor ${ }^{1}$ requires a tailored made method to the most abrogated social group of a society. In this article the intervention of Newfrontiers churches with the poorest of the poor, a reformed biblical basis for community transformation and an intervention model, illustrated in Evariste's milk project, is set out.

\section{Concise historical overview of methods used for the poor}

The method of 'mission from the ground up' was used by Schreiter (2010:24) for accompanying the poor. It is a bottom up approach that involves solidarity with the poor and the weak, but fails 1.The 'poorest of the poor' is defined as follows; 'by looking at a person's standard of living relative to others in the community or nation'
(Grigg 1997:159-160). The identification of the 'poorest of the poor' is not measured in terms of 'material or economic level, but rather of capacity to own and consume goods and services and opportunities for development' (Grigg 1997:159-160). 
to empower them. The Bare-Foot Approach of B. Roy and J. Hartigen is an initiative that has been an extremely successful scientific and social sciences approach to help empower the poor, but has neglected the role of faith and religion. 'The approach that big donors and Western-conditioned experts have taken to reach the poor - forget about allowing the poor to develop themselves - has been patronizing, top-down, insensitive, and expensive' (Roy \& Hartigen 2008:67). According to Roy and Hartigen (2008) in solidarity with Schreiter (2010) this approach overlooks the gospel that will speak with its clearest voice when it directly engages in the empowerment of the poor through a biblical framework of an understanding of poverty. The poor often do not conceive of themselves as being able to contribute towards missions. 'Both the rich and the poor are to participate in missio Dei because it is neither a mission of the poor nor the rich alone' (Bowh Si 2008:94). The first mission was theologically driven by mission ad gentes [to the nations] and focused on Matthew 28:19-20 (cf. Schreiter 2010:13): obedience to the Great Commission, cross-cultural in nature, to a much broader 20th century approach based than on transcending cultural and social barriers and transforming them in the formation of a new humanity and new community (Eph 2:16).

The approach from the beginning of the 18th to middle of the 19th century was called 'sharing what we have' which means sharing the developments of Western civilization, namely education, health care, agricultural technology and all other developments with the focus on passages such as Matthew 25 - the parable of the final judgement - or in Paul's injunction of Diaspora Christians to contribute financially to the church in Jerusalem (cf. Schreiter 2010:14).

The approach from the middle of the 19th century was 'mission out of surplus' that allowed for all Christians to participate in missions through giving (cf. Schreiter 2010:13). The approach from the middle to the end of the 20th century was participation in God's mission theologically motivated by the concept of missio Dei. It is as part of this movement that the empowering of the poor for active mission of Newfrontiers is a contribution to developing a theology for the poor. The reformed Pentecostal-charismatic theology of Newfrontiers churches is an expression of the 'empowering the poor' movement to participate in the missio Dei. Its engagement strategy with the poor is a community-based approach that 'challenges injustices, changing culture through education, demonstrating God's provision by careful stewarding of God's resources (e.g. through farming) and so on' (Ring 2011:7). It is based on a theology of the poor or missions that can be termed embracing the poor (Adams 2011). It is a prophetic mission's movement with a pneumatological focus in that 'the missio Dei is also the missio Spiritus' (Yong 2010:48).

\section{A mission of nurturing that reveals the nurturing character of God}

The image of curds and honey (Is 7:15) symbolises the food of the poor (cf. Motyer 2011:46): 'through the abundance of milk-production he will eat curds' (Is 7:22; Motyer
2011:48-49), and the diet of the survivors will be curds and honey. In Isaiah 55:1 the thirsty ('whoever has no money') are exhorted 'to come and buy - for no money, at no cost - wine and milk'. In the book of Isaiah the image of milk is representative of restoration (Is 60:16) and of the inclusion of the nations in covenant blessings and justice (Is 66:11). It is a wonderful image in which Isaiah tells Israel and us that the Lord's intentions are to gather people from all the nations into the kingdom to 'suck the milk of the nations' (Is 66:11). ${ }^{2}$ It is, according to Mouw (2011):

a striking nurturing image - the reality of many cultures and national identities can be, in God's program for the renewal of creation, a life-giving resource, an opportunity for mutual growth and encouragement. (p. 17)

It is an image of nurturing and provision that, for the poor who struggle with basic nutritional needs, reflects the nature and character of God as the sovereign God who provides for their most basic human needs, is revealed by means of the riches of the pagan world that would become tributary to the advancement of the true religion (Is 60:16). ${ }^{3}$ It involves the recognition that God is the One who provides for the most basic needs of the poor ${ }^{4}$ and that there is no limit to the riches at his disposal to serve. Thus, the God of Old Testament Israel is revealed as the one true and eternal God (Is 49:23). ${ }^{5}$

\section{The image of milk}

The image of milk reveals God as concerned with the day-today lives of the poor and involved in every aspect of human life. Missionaries taught that it is necessary 'just to do evangelism and save people's souls' (cf. Corbett \& Fikkert 2012:45). A longstanding debate has been waged as to which comes first: the physical or spiritual responsibility in the fulfilment of the missio Dei. Holistic mission involves more than simply a holistic approach of social upliftment and gospel presentation, but an integrated vision for community renewal through participation in the missio Dei. It involves an openness to learn lessons from the past and apply them to our present multicultural context. Newfrontiers is an enigma being charismatic and Calvinistic, based upon an unusual combination of reformed theology and charismatic experience (cf. Virgo 2001:62).

\section{The empowering of the poor for active mission}

The approach of Roy and Hartigen (2008:71) is a social sciences approach in which 'Empowerment is about developing the capacity of the poor to solve problems, to make choices, and to have confidence to act on them'. The approach of Newfrontiers is grounded in a theology of the poor in which 'the poor can be lifted from abject poverty to

2.The exhortation is about Jerusalem with whom they will be 'exceedingly glad with her ... all you who mourn over her' (Is 66:10 New American Standard Bible - NASB). She is compared to a 'nurse' you will 'be satisfied with her comforting breasts' ( $v$. 11 NASB) Jerusalem will drink the milk of nations.

3.'Thou shalt suck the milk of the Gentiles' (Is 60:16).

4.'And thou shalt know' (Is 49:23).

5.'And thou shall suck the breast of kings' (Is 49:23). 
active mission' (cf. Ring 2011:7) founded on 'the kingdom mandate of Isaiah 61:1-3' (Ring 2011:7). In Isaiah 60:4 the nations come gathering to God's people because of 'your light ... kings to the gleaming light of your outshining' (Is 60:3; Motyer 2011:290). 'Light' is a metaphor for truth, revelation, the future eschatological glory of the habitation of God's people (Is 60:2,4) and the glory of the Lord (Is 60:3, 19-20). 'Each of the poems ${ }^{6}$ looks forward to the Lord's covenant' (Motyer 2011:289) - the new covenant in which the glory of the Lord will be upon his people so they will shine out and 'beam radiantly' (Is 60:5; Motyer 2011:290). They also will have an abundance ('the resources of the nations will come to you' - Is 60:5) so that they can be a blessing. It is about the wealth coming to God's people so that the gospel can be carried out. Isaiah envisions a time when the poor are restored and able to contribute to the community - economically, socially and spiritually - and will therefore be a blessing.

\section{The relation of the kingdom mandate in Isaiah and the Gospel of Luke}

Bosch's missional reading of Luke begins in 4:16-30 with Jesus' ministry, applying the kingdom mandate of Isaiah 61:1-3 to himself. 'Jesus' contemporaries would have interpreted Isaiah 61:1-2 in terms of violent political liberation' (Goheen 2005:248). For Bosch (in Mbazumutima 2007:85), Luke's society understands the poor to be 'an all-embracing category for those who were the victims of society'). Jesus proclaims the favourable year of the Lord, but refuses to announce the day of vengeance. In Luke 4:18-19 the Lord himself ends the quotation before the 'day of vengeance of our God'. Isaiah 61:1-3 informs a reading of Luke 4:16-30 where Luke places the emphasis on social-responsibility in the context. The echo of Isaiah emphasises the witness and enables the reader to have a greater appreciation of the fullness the author intended to communicate. 'The kingdom mandate of Isaiah 61:1-3 shows how, in the space of three verses, the poor can be lifted from poverty to active mission' (Ring 2011:7). The image of 'Oaks of righteousness' is one of firmness and immovability of the personal character of righteousness. One of the breakdowns in society is in terms of righteousness that is more fundamental than a breakdown of justice or fairness. It is righteousness that classifies 'the Lord's plantation' and 'display His beauty' (Is 61:3). The call to serve as 'the Lord's Priests ... Ministers of God' (Is 61:6) is directly bound with the image of 'oaks of righteousness'. It is the empowering and transforming impact of the Holy Spirit resulting in that 'they will be called oaks of righteousness' (Is 61:3). A reading of Luke 4:16-30, which takes the echo of Isaiah 61:1-3 into consideration, ensures that the focus is not one-sidedly placed on social-responsibility or justice, because that will prevent our prophetic mission from becoming purely political (cf. Bosch 1991:402-403). Only if justice or vengeance is secondary and love primary, as is seen in the wider covenant context of Isaiah $61: 1-9,7$ is the transforming power of

\section{Servant songs.}

7.Isaiah 61:8-9 indicates what the signs are of the 'everlasting covenant': an offspring, known among the nations, and recognisable as the offspring the Lord blesses.

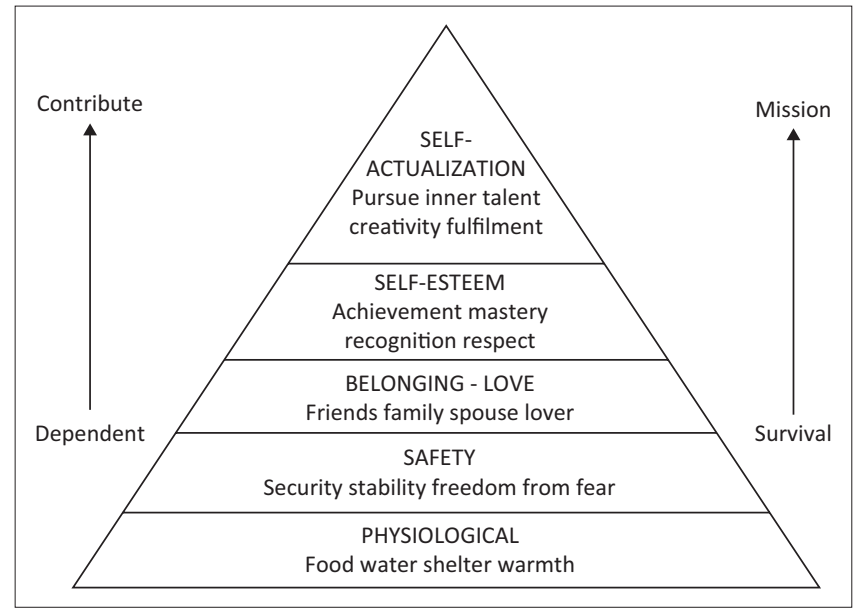

FIGURE 1: A mission's model based on Maslow's pyramid of needs (Ring 2011:9).

evangelism evident in development, advocacy, solidarity and empowerment of the poor. Isaiah 61 shows (Ring 2011):

how God's heart for the poor is not just to improve their circumstances, but to lift them into fully functioning members of the body of Christ and have them involved in effective mission. (p. 21)

'Luke's Gospel does not simply "patch up" the lives of the poor by lifting the poor out of poverty to a better lifestyle' (cf. Ring 2011:7), but enables them to recognise the resources God has given them - the unique gifts of service ( $1 \mathrm{Pt} 4: 10$; Ep 4:12) - and to be involved in effective mission to the community. The poorest of the poor can become 'fully functioning members of society' (Ring 2011:22), missionaries to the community that Isaiah calls 'oaks of righteousness' (Is 61:4-9). The diagram (Figure 1) illustrates that restoration is a journey towards greater community participation through the use of the gifts from the Lord. It is a restoration in terms of physical-well-being, personal well-being, social well-being, cultural well-being and spiritual well-being (cf. Myers 1999:81). The uniqueness of the Newfrontiers' approach is that it empowers the poor through participation in the missio Dei.

\section{The partnership of Newfrontiers churches and Evariste Ndayirukiye}

The empowering of the poor is the 'prophetic mission' of Newfrontiers church that is a prophetic voice in a critical moment (Kairos) in the history of Burundi. The vision is to help the poor to develop a sense of ownership, God-centred self-respect and self-esteem. The mission's approach of Newfrontiers is prophetic in that the poor are empowered to envision an alternative future through recognising their potential and becoming agents of transformation. The vision of Newfrontiers churches is to help the poor identify their skills and available resources. It is more than an approach of solidarity with the poor through self-actualisation; it is the empowerment by the Holy Spirit to become agents of active mission in their communities. 'It is necessary for people to have a sense of self-worth and dignity in the process of change' (Bragg 1984:160). The model is for human beings to 
become 'more fully human' and to see themselves less as victimised and alienated, but to discover their latent God given potential at which point human spiritual change regeneration and reconciliation - accompanies the social transformation. It finds affinity with another approach, namely the Barefoot approach: 'Underlying the Barfoot approach is a firm belief in the knowledge, creativity, practical wisdom, and survival skills of the rural poor' (Roy \& Hartigen 2008:72). The underlying of a biblical empowerment of the poor is the equipping and release of the poor through the recognition of spiritual resources to function as agents of the missio Dei - God's agents of community transformation. In 2007 Evariste Ndayirukiye launched such a pilot milk project that had an underlying biblical grounding and foundation as an initiative to transform his community, one of the poorest communes in Burundi that is listed among the four poorest countries in the world.

\section{The Newfrontiers churches self-identity}

Newfrontiers is a unique network of like-minded churches ${ }^{8}$ that practice biblical generosity and spiritual equipping of the poor. They are deliberate to foster koinonia in their mission's relationships and draw those who serve the poor into a spiritual fellowship and partnership in the formation of a Holy Spirit led intervention with the poor. The character of these intentional relationships is that they foster a profound depth of intimacy with men such as Evariste Ndayirukiye from Burundi who serve the poor. Newfrontiers represents two theological traditions: the Pentecostal-charismatic and the reformed church tradition. It is therefore not identical to Pentecostal-charismatic Christianity. Joel Edwards, a leader of the British Evangelical Alliance said in an interview with Terry Virgo that, 'You're the only reformed charismatic group I know and that holds a lot of challenges' (Virgo 2001:62-63). Virgo (cf. 2001:62) was shaped in his reformed thinking by such men as Martin Lloyd Jones, John Stott, J.I. Packer and C.H. Spurgeon and influenced by works such as A.W. Pink's book The sovereignty of God (cf. p. 61) and L. Berkhof's Systematic theology (cf. p. 37).

\section{The Newfrontiers Pentecostal-charismatic theology of engaging the poor}

The socio-spiritual context of the Newfrontiers Pentecostalcharismatic tradition has enabled it to identify with the 'poor', a characterisation that, in Pentecostalism, is 'a religion of the poor, not a religion for the poor' (Ma 2007:29). One of the reasons why the Pentecostal-charismatic Christianity of Newfrontiers churches has been effective in multicultural engagement with the poor is that, central to its socio-spiritual upliftment, is the ministry of the Holy Spirit. It is 'through powerful experiences such as healings, baptism in the Spirit, prophecy, and miracles, as well as drastic conversion experiences is in itself a social up-liftment' (Ma 2007:29). The appeal of Pentecostal-charismatic spirituality to the poor is that it 'includes the real level of human existence, including

8.The name Newfrontiers embodies the mission's identity and is an association of churches united by the common purpose of joining together on a mission (cf. Virgo 2001:145). particularly physical and material aspects, as well as spiritual dimensions' (Ma 2007:29). The restoration of the church to the lifestyle of the first church as recorded in the book of Acts, a characteristic of Pentecostal-charismatic Christianity, is central to the mission's vision of Newfrontiers churches. Its mission praxis is based on a sensitivity to the Holy Spirit and a recovery of the compassion and tenderness of the early church to the poor. 'In Acts we see a spontaneous outbreak of the Holy Spirit-inspired generosity which overwhelmed the young church' (Virgo 2011:97). A community consciousness is being fostered where the church members of Newfrontiers churches embrace 'God's desire for a people sensitive to the needs of the poor and homeless' (Virgo 2011:97). Virgo (2011:89) speaks of this consciousness as the community's centre of gravity and 'a community whose center of gravity is in God ... Pentecost gave birth to an immediate Holy Spiritinspired jubilee of caring and sharing' (Virgo 2011:89, 91). Newfrontiers churches are purposeful in building a 'generosity factor' into its church culture (Virgo 2011:90), which later served its vision for the nations.

\section{The Newfrontiers churches historical roots of engaging the poor}

A common vision and mission's identity of Newfrontiers churches was established by Terry Virgo (2001:46), based on Acts, for example, texts such as 2:1 'they were all together' meaning they shared intimate fellowship. The foundation of Newfrontiers mission identity is biblically grounded in Galatians 2:10 and the exhortation, 'Remember the poor' (cf. Virgo 2011:97) and is thus a movement in obedience to the grand narrative of Scripture. It was at the Brighton 1998 leaders conference, attended by 2500 people from approximately 30 nations where Simon Petit made an urgent and insistent appeal to remember the poor (cf. Virgo 2001:275). ${ }^{9}$ 'In 1998 we were overwhelmed by God's apostolic mandate to us "to remember the poor"' (Oliver 2010:46). The mission movement was launched through a sermon delivered by Simon Petit who led the Newfrontiers Church Jubilee in Cape Town. They began to plant Newfrontiers churches throughout Africa as a response to an 'apostolic commission' (Ring 2011:1). Petit ignited a flame through his message on 'the biblical centrality of God's compassion for the poor and our responsibility to give high place to caring for them as an outworking of our commitment to the gospel' (Virgo 2001:276). The central message of the sermon was that the poor are 'an integral part of God's apostolic commission to the church' (Virgo 2001:276).

The response of Newfrontiers within the UK was the oneyear Act 2000 Initiative (cf. Ring 2011:1) that was launched at the Stoneleigh Bible Weeks in 1999 at which $£ 2 \mathrm{~m}$ was raised, including $£ 300000$ for work among the poor and disadvantaged in the UK (cf. Virgo 2001:275). ${ }^{10}$ The rediscovery of missions by Newfrontiers was a vision that

9.Virgo (2001:275) identifies the urgent and insistent appeal of Simon Petit at the Brighton 1998 leader's conference as 'most significant of all'. It was 'greeted as it was by an immediate standing ovation from the gathered crowd, it has resulted in measurable and thoroughgoing action' (Virgo 2001:275).

10.This amount was used to 'kick start' many missions' works throughout Newfrontiers (cf. Virgo 2001:275) 
emphasised more than personal evangelism. Virgo (2011) writes about the new vision:

Though our (local) church was keen on missionary work, it was never taught that ' $\mathrm{He}$ will bring forth justice to the nations ... He will not be disheartened or crushed until He has established justice in the earth; and the coastlands will wait expectantly for His law (Is 41:1, 4)'. (pp. 120-121)

The vision of Newfrontiers went through a titanic shift from simply serving the poor in its own ecclesiastical structures to serving the poor and needy of the nations. Prior to this, 'missionary work consisted of isolated stabs at Satan's strongholds' (Virgo 2011:121). The shift of Newfrontiers to embrace the poor was a paradigm shift comparable to those of Peter and the Jewish Christians to include the Gentile Christians in the table fellowship as equals.

The theological assumption that underlines Pentecostalcharismatic missions is, according to Ma (2007), that:

any transformation of society begins with individuals, and a change in a person begins with his or her inner (in this case, spiritual) being. This inner change involves not only a conversion experience, but also an encounter with God's reality, often through baptism in the Holy Spirit. (p. 31)

In the Newfrontiers approach, mission's failure is defined as 'falling short of the glory of God' and its objective is 'to take full advantage of his grace' in order to achieve a life of fullness, and not 'to fall short of its full potential' and miss 'the mark of God's high ideal' (cf. Virgo 2001:169).

\section{Empowering in a post-war African context}

Although a small country, Burundi is one of the most densely populated countries in Africa. The population and availability of land resources places it in the same class as Japan and South Korea. Burundi (10 745 square miles), is slightly smaller than the State of Maryland in the US, but it holds nearly twice as many people - about 10 million, according to the UN Development Programme which is roughly $40 \%$ more than a decade ago (cf. Keenan 2015:60-69).

The poor of Burundi have the perception of limited economic resources and equitable opportunities for obtaining the necessities of life, education, employment. This perception contributed significantly to the genocide in Rwanda and the 14 year civil war in Burundi. It shares in the past dire economic poverty of Rwanda: the unstable political climate in which there were little or no foreign investments and poverty interventions, and so, combined with an on-going unstable political situation in Burundi, it continues to be the breeding ground of the violence and war (cf. Nothwehr 2010:122). It is economic discrepancies and divisions among ethnicities and tribal groups that threatened the formation of any cohesive national unity (cf. Nothwehr 2010:122) none more so than in Burundi. The theology of missions of Newfrontiers is dealing with and addressing the root of the problem, namely the incompetence, injustices and enfranchisement fostering a general sense of distrust among all citizens. It is about the eradication of false perceptions and not taking the side of the oppressed in solidarity against the rich. A transformation approach of equal distribution of opportunities is important so that the origin of inequality is not projected to God. God has called us to not only serve the poor, but has given us a mandate to empower the poor so they can join us on world mission (cf. Oliver 2010:46).

\section{A biblical theology for the empowerment of the poor}

The image of being weaned off milk in Isaiah is used for those who have been brought up and nurtured in the knowledge of God and sound biblical interpretation, to whom God reveals his message. 'Whom will $\mathrm{He}$ teach knowledge? And whom will He make to discern the message? Those weaned off milk, removed from the breasts!' (Is 28:9). The poor are the 'downtrodden' those who have been 'wounded in spirit' (Is 66:2).

\section{A contextual theology: 'water buffalo theology'}

'Water buffalo theology' is theologically contextual in an approach Kosuke Koyama calls to be 'sandwiched between' the Bible and the culture. 'Sandwiching' or what Lygunda Li-M and Van Aarde (2017) calls missional exegesis involves the bringing of experiences from cultural contexts into dialogue with the biblical text. It is distinct from a missional reading of the biblical text in which the exegesis is filtered through the spectacles of the reader. Missional exegesis is the interpretation of the biblical text from a specific missional location and a biblical view Scripture. The necessity for this is that knowledge has shown always to be contextual 'knowledge is always contextual - whether we like it or not, we and our knowledge are always conditioned by our circumstances' (Padilla 2012:47). Contextualisation has to do with the shape and the presentation of the message in the context of the people to whom it is addressed and it concerns the application thereof. Missional exegesis is the process through which the content of the message is discovered in a specific missions context.

\section{A missional method of exegesis}

In order to engage with those whom he wanted to be reached with the gospel, 'Koyame decided to read the Bible as if he was standing alongside a water buffalo in a rice paddy' (Mouw 2011:17). Koyame interpreted culture as the first step. Biblical passages on water suddenly stood out. The interpretative approach of Koyame was to position himself as a missionary between the Bible and culture in what he calls to be 'sandwiched between' the Bible and the day-today realities of rural Thailand. In this method, Mouw (2011) writes that the missionary exegete:

must then engage in a two-way exegesis, working at two interpretative processes: they have to interpret the questions and the answers of the culture in which they find themselves, and then they must bring those questions and answers to the Bible, in order to interpret anew what God has to say about such matters. (p. 18) 


\section{The erecting of a theological framework and scaffolding}

The biblical principle of engagement with the specific context: The perpetuation of all church traditions has been undermined by postmodernism in which theological tradition and identity can no longer simply be maintained through strong denominational loyalties. Postmodernism has undermined every church tradition and denominational scaffolding. The mission's theology of particular Christian traditions such as reformed, Lutheran, Baptist or Pentecostal-charismatic has traditionally been the primary point of engagement with new missions' contexts. In Koyame's approach it is the primary questions that are the point of contact and engagement between the culture and the biblical text. Onto this, then, a particular theological tradition can be engrafted. In Koyame's case it was his reformed theology of 'None but Christ reigns' that provides the theological context for engagement, that is, the biblical texts on water jumping from the missions, or the cultural context of the monsoon season in which both the buffalo and field worker had to find ways of staying dry during the onslaught of the monsoon rains. The reformed theological context was that 'God rules from a place above the rains and the floods; God stays dry!' (Mouw 2011:17). The principle is, first, to engage the missional context; second, to cross the missional bridge by coming alongside those in their specific location; and third, to allow this to lead to the text before attempting to cross the theological bridge. Too often in missions we begin with our own context or specific theological context with the result that we do not cross the cultural bridge.

\section{The reformed scaffolding and approach to the poor}

In the book of Isaiah, milk is an image for a holistic and integral ministry to the poor that characterises the reformed scaffolding and approach to them. Central to the reformed scaffolding is also a community transformation approach.

\section{The biblical perspective of the poor in Isaiah}

In the book of Isaiah, the essential ingredients for a biblical perspective of the poor is developed in terms of characteristics such as righteousness and peace. Righteousness and peace are what God will give and accredit to the poor.

Righteousness: Righteousness is a central thread of the book of Isaiah. God desired a harvest of righteousness (Is $5: 7)$, right practice and right principles. Righteousness and judgement are inseparably bound together in Isaiah (Is $1: 21 ; 2: 7 ; 9: 7 ; 16: 5 ; 32: 1 ; 56: 1 ; 59: 9$ ). Righteousness is the essential characteristic for walking on a 'perfectly level' path (Is 26:7). The Lord 'level(s) the track for each righteous one', the 'upright one' (Is 26:7). Isaiah makes the connection between learning righteousness through judgements (Is 26:9) and the wicked who never learn righteousness although they are shown favour (v. 10). It is the person who 'walks in complete righteousness' (Is 33:15) who will have fellowship with the Lord and who will 'reside in the heights' (Is 33:16). The root cause of poverty is when there is a breakdown of social relationships in respect of righteousness. The believer is to long for the milk of the Word that makes a mature and healthy relationship with God (1 Pt 2:2-3) and others (1 Pt 2:4-5) possible.

Peace: The failure of peace is one of the factors for the breakdown of 'the four foundational relationships' (Corbett \& Fikkert 2012:74) which is a root cause of poverty in Africa. According to Buys (2013),

The announcement and proclamation of peace is accompanied by the declaration:

of its conditions, of which the principle one is the observation and fulfilment of the righteousness of God - no peace without righteousness (Ps 72:3-7; 85:9-11; Is 31:17)! (p. 76)

Isaiah identifies the absence of personal righteousness in the nation of Israel and the people of God which was a root cause of the exile. The reason for the failure of peace is a failure to pay attention to God's commands. If Israel had paid attention then 'Your peace would have been like a river, and your righteousness like the rollers of the sea' (Is 48:18). Peace, as described in Isaiah 66:12, is what wayward Israel experienced after returning to the Lord. It is expressed through the image of a baby who has obtained the essential nutrients and comfort from drinking from the breasts of its mother (v. 11), an intimate image of God as a nursing mother. $^{11}$

\section{Milk as essential for healthy physical and spiritual development}

One of the biggest health problems of the poorest of the poor is that the mother's milk does not contain the necessary nutritional value to stimulate health development and growth in the child, because the essential vitamins and iron is lacking in the mothers' diets. A result is that the mental faculties of the child are underdeveloped. In Isaiah 66:11 the image of a child drinking from its mother is used for the restoration of Israel's relationship with God. Milk is a source of spiritual nourishment (1 Pt 2:2-3). It is depicted by the image of a sucking child who gets satisfied by the mother's comforting breasts: 'that you may suck and be delighted with her bountiful bosom' (Is 66:11 NASB). The image expresses the restoration of the nutritional value of the milk and it depicts the restoration of the former glory of Jerusalem. Jerusalem is the only city that has been destroyed more than once $^{12}$ and has been restored to more than its former glory. It is indicated by images such as 'enlarge the place of your tent' (Is 54:2); 'for right and left you will burst out and your seed will take possession of the nations' (Is 54:3); and 'in their land they will possess twice as much' (Is 61:7). Only God is able to do this. The image of milk is used in Isaiah for the

11.In Isaiah 59:9-13 wayward Israel confesses her sins and is restored in her nt, and the rumblers will learn gratitude' (Is 29:24). Israel will learn to revere the name of the Lord and hold it in terror (cf. Is 29:23)

12.The Babylonian and Roman destruction of Jerusalem. 
blessing of the Lord (Is 7:22; 60:11; 66:11) and the extension of God's kingdom (Is 55:1-2): ${ }^{13}$

[...] and you will suck the milk of nations, and you will suck the breasts of kings, and you will know that I am Yahweh, your Saviour, and you're Redeemer and your Potentate of Jacob (Is 60:16).

'Potentate is his absolute power to do whatever he wills' (Motyer 2011:291).

\section{Restoration of broken relationships in the resolution of poverty}

Brent L. Myers (1999) proposed that:

Poverty is a result of relationships that do not work, that are not just, that are not for life, that are not harmonious and enjoyable. His 'understanding of poverty as a result of broken relationships affected by sin within ourselves, with the community, with those we call other, with the environment, and with God. (p. 87)

'He highlights the fact that both the poor and the non-poor undergo poverty since they are all made in the image of God, are fallen and are in need of redemption' (Myers 1999:63, 89). 'Poverty is the absence of shalom in all its meanings' (Myers in Sunquist 2013:391). Poverty in the African context is directly affected by fear and relationships of distrust. 'Poverty is rooted in broken relationships, and so the solution to poverty is rooted in the power of Jesus' death and resurrection to pull all things into right relationship again' (Corbett \& Fikkert 2012:73). It is important to realize that 'we are not the reconciler; Jesus is. However, we are His ambassadors, representing His kingdom and all that entails to a broken world' (Corbett \& Fikkert 2012:73):

Material poverty alleviation is working to reconcile the four foundational relationships ${ }^{14}$ so that people can fulfil their callings of glorifying God by working and supporting themselves and their families with the fruit of that work. (Corbett \& Fikkert 2012:74)

The images of 'Rebuilder of the breach' and 'Restorer of paths to inhabit' (Is 58:12) have in view the restoration of broken relationships. Yahweh 'saw that there was no man' (Is 59:16) to intercede. 'He felt appalled that there was no one to interpose' (Is 59:16). It was thus the righteousness of Yahweh that accomplished salvation for him, sustained him and interposed. It is because of the righteousness of Yahweh that believers can be called 'Oaks of Righteousness' (Is 61:3).

\section{A holistic integral ministry approach to community transformation}

Buys (2013) comments as follows with regard to community transformation:

Community transformation is the reversal of sin, the restoration of God's order in creation, and God's intent for humans to be full image-bearers of God.

Community transformation through a holistic response to poverty takes seriously the effects of sin over all of life and the

13. References to the 'eternal covenant' (Is 55:3).

14.The relationship with God, with self, with others and with the rest of creation. earth - the sin of Genesis 3 that alienated men and woman from God, from self, form others, and from the environment. (p. 90)

He (Buys 2013:95) also says that, 'Community transformation 'must go deeper than merely changing conditions of poor socialization, releasing untapped potential in people and communities, or changing environmental conditions'. The holistic approach, according to Poorta (2010) is that:

the Hebrew worldview and understanding of life as a total unit, not divided into spiritual and material world. This dichotomy or separation between material and spiritual world is a product of the Greek worldview and philosophy of Plato. (p. 299)

In the Hebrew worldview, relationships are the highest, while alienation is the lowest (cf. Sunquist 2013:391). Poorta (2010:299) asserts that the worldview prevalent in the Hebrew context is the same as the African worldview, where there is no separation between sacred and secular spheres'.

\section{The initiation of a community transformation initiative}

Community transformation takes 'a good look inside before thinking about looking outside' (Buys 2013:96). In the holistic integral ministry an intervention can be initiated from either the leg of the spiritual need or the material need without the neglect of the other leg. The approach, which is exclusively focused on the spiritual need with the neglect of the social, economic and political issues that affects them, tends to be too spiritual. This is a highly fatalistic view. The approach that is exclusively focused on the social, economic and political misery of people is based on the view that complete change must be realisable immediately. It is based on the view that the kingdom of God is a fully realisable reality in this broken and fallen world. The goal of a community transformation is to identify, dismantle and disempower 'systems and people who prevent the poor from becoming secure and becoming contributing members of society' (Buys 2013:80). The approach of Buys (2013:80) towards the poor is community based; to create a community of spiritual support: 'The responsibility of the community is stated as "you shall support him" so he can continue to take his place in the community (Leviticus 25:35)'.

One way of doing so is to enter into a covenant relationship for change between communities: a Christian church, as a covenant community, enters into a covenant with the community in need. The biblical warrant for such a covenant is given in Isaiah 42:6c-7:

And I will appoint you as a covenant to the people, a light for nations; to open blind eyes, to bring out the bound from confinement, from the house of restraint those inhabiting darkness. (Motyer 2011:202)

Isaiah talks about "the role of all believers as priests in the New Covenant in Isaiah 61:6, and about the Gentiles, "'I will take some to be priests, to be Levites", says the Lord' (Is 66:21). Such a covenant can affirm both spiritual and socio-political involvement. It is an extension of the Lausanne Movements covenant in which, 'we affirm that both 
evangelism and socio-political involvement are part of our Christian duty' (Buys 2013:92). The reformed understanding of the transformation of individuals and communities is based on going 'much deeper than merely changing conditions of poor socialization, releasing untapped potential in people and communities, or changing environmental conditions' (Buys 2013:95). The approach of Newfrontiers churches is also community driven, beginning with 'to understand the needs of the community and our role is to know from Him what part we should play in meeting those needs' (Ring 2011:21).

\section{The Pentecostal-charismatic scaffolding and approach to the poor}

The restoration of hope and confidence is central to an intervention with the poor. The Pentecostal-charismatic approach of Newfrontiers is led and guided by the Holy Spirit. This approach, however, does not preclude a carefully structured intervention and the stewardship of human and financial resources.

\section{A gospel motivated intervention to restore hope and confidence in God}

The approach of Newfrontiers in its intervention is, in essence, to enter into covenant relationship with Evariste with the goal to empower the poor and disadvantaged and to become 'Oaks of righteousness' by enabling them to become fully functioning members of society. The poor have lost all confidence in their own ability. The humanistic solution is to restore the confidence in their own potential, but the biblical approach is to create a vision of new or renewed confidence in God. Newfrontiers endeavours to open the eyes of the blind through the gospel to see the resources God have given them (cf. Ring 2011:21). It involves breaking a dependency mentality that is a root cause of poverty. Ring (2011:8) considers it the reason why 'the individuals changed from poverty to active mission. This is closely allied with the gospel'.

\section{He (Ring 2011) further comments that:}

There should be an eternal dimension which they are exposed to, for only the gospel can bring about the heart transformation that will truly lift people into a place of hope and fruitfulness. (p. 7)

Although it is not specifically expressed by Newfrontiers, the vision for the poor is to restore hopefulness and remove despondency, because the poor are caught up in a cycle of poverty ${ }^{15}$ fuelled by despair. Poverty is a cycle of dependence in which people perceive themselves to have no abilities or talents. Restoration is a process in which renewal begins with a renewed confidence in God and self.

A suggested intervention model with the poorest of the poor has to transform the hopelessness and address the fallacy that the problem is fundamentally the result of having no resources. A shift in self-perception and the recognition of personal resources and talents is an essential process to restore confidence and hope. 'People need self-esteem to be fully human' (Bragg 1984:161). The restoration of the selfconfidence process requires a second and simultaneous process of confidence in God without which a culture of selfreliance can be fostered. It is through a recognition of the resources God has already given that the pervasive attitude of pessimism is transformed into an attitude of expectation. Myers (1999:88) correctly argues that any response to poverty must be spiritual and must aim at restoring broken relationship. The reason is that poverty distorts the image of God - imago Dei - in people, Myers $(1999: 88,188)$ argues that poverty is fundamentally spiritual:

Poverty alleviation is the ministry of reconciliation: moving people closer to glorifying God by living in right relationship with God, with self, with others, and with the rest of creation. (Corbett \& Fikkert 2012:74)

Healing from the 'dependency virus' or escape from the 'dependency trap' requires new processes to ensure renewed thinking and behaviour. Many intervention models or approaches neglect to introduce new processes. Two fundamental processes are necessary and essential (Figure 2):

These processes form part of the intervention strategy and the success of it will depend on the planning and implementation thereof.

\section{Planning a ministry intervention and teaching and training on stewardship}

Planning a ministry intervention with the poorest of the poor is essential for a high likelihood of success. In The Poor deserve the Best: a manual for good practice (Ring 2011), key indicators of good practice are identified for Newfrontiers churches. These are based on eight spiritual indicators Newfrontiers churches seek to instill: spiritual oversight, ministry leadership, hearing God, vision, gifting, biblical values, gospel and change and nine material or secular indicators: who, when, how, why, team, finance, network, resources, and life (cf. Ring 2011:32). According to Ring (2011), for Newfrontiers there are two indicators to measure the effectiveness of an intervention:

The first includes matters related to integration of the ministry in the local church, leadership of the project, and the spiritual impact it can make. The second relates to practical issues specific to the ministry, such as handling finance. (p. 4)

The success of a poverty intervention will ultimately rest upon the exercise of stewardship and in the fulfilment of the biblical mandate of stewardship (Gn 2:15; Ex 19:4-6; Ml 1:6; 1 Pt 2:5; 9-10, 4:10-11; Rv 5:10, 20:6).

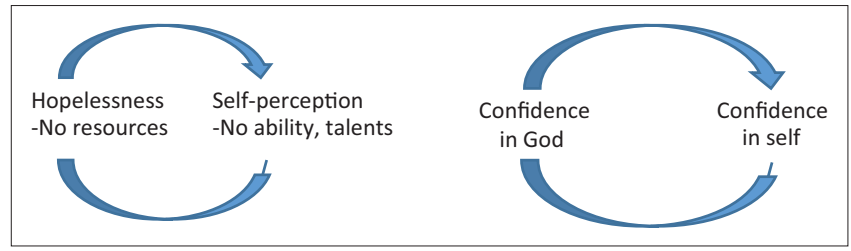

FIGURE 2: The poverty cycle and the cycle of restoration and renewal (own research) 
The planning of a strategy of intervention necessitates an understanding of the historical context, the history, an analysis of the situation, and community participation and ownership. The community intervention milk project of Evariste Ndayirukiye's is a concrete example of such a community owned project.

\section{Burundi's historical context}

Burundi's first democratically elected president was assassinated in October 1993 after only 100 days in office, triggering widespread ethnic violence between Hutu and Tutsi factions. Ethnically Burundi is similar to its better known neighbour, Rwanda that also suffered from the conflict between Hutu and Tutsi tribes. The 12-year civil war killed an estimated 300000 civilians and severely affected the country's economic and social development. It was ranked $184 / 188$ on the scale of the world poorest countries according to the UN scales of poverty after the civil war.

\section{Analysis of the problem in Burundi}

Families are caught in a cycle of poverty: declining food intake, stretched government services (education and healthcare), little to no access to job or markets to sell goods or services. Now there is also an issue of dwindling land resources for livestock and agriculture. The problem is that, although the majority of the Burundian population are farmers, they have been marginalised by economic and government structures, and represent one of the poorest countries in the world. ${ }^{16}$ The issue was how to bring about community transformation with no infrastructure. The majority of the Burundian population consider their situation of poverty fatalistically. Therefore, it is only by concrete examples of transformation that visions for an alternative future can bring about a new vision. Intervention with the poor is to fully include them in God's purposes for the nations. It will transform their fatalistic attitude. The place of desperation of the poor will then be exchanged for a place of equal position and acceptance in God's kingdom.

\section{A community transformation initiative}

The issue was how to empower a community without leaving them dependent and keep them from making decisions on their own. 'People cannot be developed; they can only develop themselves' (Nyerere 1974:58). Empowering the poor begins with giving them the right to decide for themselves how they want to improve their quality of life (cf. Roy \& Hartigen 2008:68). Evarsite gave to his village the opportunity and space to identify the core needs of the community in a transformation strategy. The poor need the opportunity and space to develop themselves. Many church based poverty interventions 'ministers to that community out of its own understanding of their needs ... This process can result in dependency and lack of ownership by the community' (Bahizi 2012:47). 'When provided with that mental and physical space, the poor can achieve wonders 16.'Development is still top-down with stronger state controls' (Bragg 1984:155). without any outside professional interference or advice' (cf. Roy \& Hartigen 2008:68).The process of social transformation is only possible if it is locally owned.

The community identified the following areas of material need:

- Income generation.

- Improved health.

- Children and education.

- The availability of time to work the land.

- Employment opportunities.

- Restoration of the land to become more fertile.

- The restoration of dignity.

The needs identified by the community are 'the resources God had given them - the people, each with unique gifting' (Ring 2011:7). Evariste Ndayirukiye followed the 'Asset Based Community Development' approach that he presented as a project to his village community. In Burundi, wealth is measured in terms of the number of cattle a person owns, but these cattle contribute to the poverty of the community instead of alleviating it. A transformational strategy had to utilise what people valued, namely cattle. The vision was for transformation of families and communities through microloans in the form of livestock. This project envisioned empowering farmers by creating a stronger dairy market for Burundi. The benefits were to enable children and families, held back by hunger to lead healthy and productive lives. It was to transform one of the poorest rural communities in Burundi through a cohesive unity that transcended socialeconomic, tribal, ethnic, or gender divisions. It also had to prevent overgrazing of fields through the containment and feeding of cattle on locally grown elephant grass. It has enabled families to send their children to school rather than following unproductive cows into the hills to find pasture. Finally, the vision was to provide a monthly income to the poorest of the poor and give to them the most basic commodity of milk as a source for income generation. The transformation approach is a solution at the village level that gives the participants control.

\section{The community as shareholders of the vision of transformation}

Training was presented to help the community learn about the resources God had given them and how to produce for market. The transformation involved training about farming cooperatives. The training taught how to access markets, increase productivity and efficiencies of scale. The families learned about the direct benefits of fresh milk to supplement the nutrition needs of infants. Cattle and land, the two commodities identified by the community, were applied to a transformational model to help the people realise the resources they had available in their context. The village had a subsistence culture and the training helped them to realise the high impact of initiative on the culture as well as on the food deficiencies of the village. For community participation 'there must be a sense of purpose and direction for what is to be implemented, with agreed goals, objectives and expectations' (Ring 2011:7). 


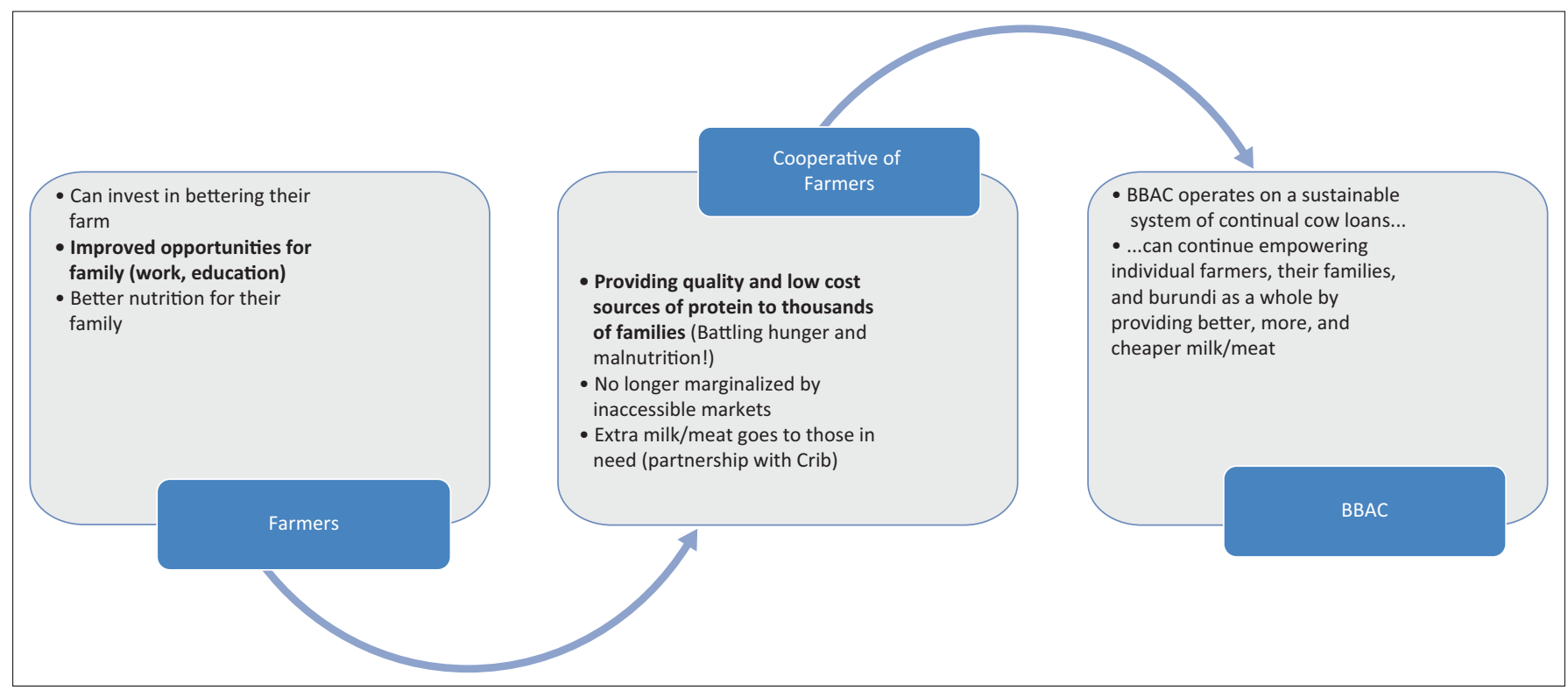

FIGURE 3: The 'knock on effect' of the grass roots community transformation initiative of BBAC (own source)

\section{The implementation of a community owned vision of transformation}

In order to transform the thinking of the Burundian people a practical demonstration was arranged: two Ankole and two Friesian cows were placed in the same pen and provided with the same fodder. The community then observed the significantly higher milk yield of the Friesian. This demonstrated that whereas the Ankole produced 1-2 liters per day for a few weeks after calving, Friesian cows produced 10-15 liters per day continuously. The community was impressed, although the demonstration was received with initial suspicion.

What began as a small project to help eliminate some of the 'useless' cattle in order to salvage more land for agricultural development, has turned into a wave of entrepreneurial excitement. A cultural value of entrepreneurship was cultivated. Each of the 100 families in the community bought a cow with the help of a revolving credit scheme. Those who owned cows, employed local people to grow the elephant grass for which they are paid. This required that the cultural importance of the Ankole cow was changed and the cultural practice of cows roaming freely for grazing, damaging the agriculture was ended. In the past the Ankole cows needed to graze for hours and the herds were often taken care of by children who consequently missed the opportunity of education. Families were taught how to take care of the cows they have, and how to collect and make use of manure for fertilizer. They were taught how to care for the environment and the damage caused by overgrazing. The transformation model was based on the poor making use of the resources available to them to become agents of transformation.

\section{The impact of the transformation vision on the community}

The transformation has resulted in a large number of people in the community being transformed. The community itself took the initiative to plant a church and embraced the vision of transformation for others. ${ }^{17}$ The poor were enlightened that they were called to participate in the proclaiming of the gospel to the nations (Eph 1:18) and received 'the immeasurable greatness of his power' (Eph 1:19) for the purpose of missions. The mission of the church is a response to and part of the missio Dei, but it cannot be simply identified with the missio Dei (cf. Bowh Si 2008:95). Self-actualisation devoid of participation in the missio Dei leads to becoming more self-reliant instead of recognising the eternal purpose of God realised through an appropriation of the internal deposit given by God to each person fully unlocked in spiritual transformation. 'The imago Dei and the missio Dei are inseparably bound up together, the missio Dei will be fulfilled when the imago Dei is fully restored' (Van Aarde 2015). 'Transformation implies the restoration of the imago Dei and the bringing into subjection of the principalities and powers within the new order of things (1 Cor 5:17)' (Bragg 1984:157). Transformation based on the imago $D e i^{18}$ is a demonstration of the love and compassion of the Lord that is distinctly different from a humanistic intervention.

\section{The compounding effect of an intervention with the poor}

In an intervention with the poor, performing acts of kindness and the goodness of the Lord must take place in a spirit of the love and compassion. It is only then that our intervention is an expression of God's love. The intervention of Evariste has had a compounding effect and influence on the Burundian society which has been extended beyond the 100 families of his village whose economical and spiritual well-being has been transformed. The 'knock-on effect' has had compounding transforming effect on society (Figure 3). It has affected the relationship between the milk farmers, co-operative farmers, the farmers who produce meat of the Ankole cattle, the 17.This community owned spiritual transformation.

18.'The starting point of mission must be the unequivocal recognition of the imago Dei in each and every human person' (Nothwehr 2010:115-116). 
growers of elephant grass, the bicycle transporters, the Crib orphanage in Bujumbura and Burundi Bio Agricultural Communities (BBAC), a small loans co-operative - all of whom have come to experience the rippling effects of God's grace. The approach of Evariste was to make disciples among the poor.

\section{Conclusion}

The vision was to see community transformation to begin to take place and the fatalistic attitude towards poverty transformed into a spirit of entrepreneurship - all this to empower the poor. The approach of self-actualisation through participation in the missio Dei is based on a holistic and biblical perspective. The approach of empowering the poor to be active in mission is instilling a 'can do' attitude in the poor to improve their own lives grounded in the trinitarian God. Milk is essential for healthy physical development in infants and so an apt metaphor for spiritual development. Poverty intervention with the poorest of the poor requires to begin with the most basic nutritional needs such as those of infants for milk in the development phase. This is thus a metaphor for the most basic spiritual needs of humanity. The community transformative initiative of Evariste Ndayirukiye identified what the poorest of the poor had at their disposal and in their hands, namely Ankole cows. These cows perpetuated the cycle of poverty, because they were 'useless'. They were substituted with 'useful' Fresian cows to improve milk production.

\section{Acknowledgements Competing interest}

The author declares that he has no financial or personal relationships which may have inappropriately influenced him in writing this article.

\section{References}

Adams, D., 2011. Embracing the poor: Releasing, resourcing and equipping the poor for world mission, Roper Penberthy Publishing, Weybridge.

Bahizi, T., 2012, 'Mission on the margins: The work of the Anglican diocese of Bujumbura in the community of Bwiza', MA thesis, UNISA, Pretoria.

Bosch, D., 1991, Transforming mission: Paradigm shifts in theology of mission, Orbis Books, Maryknoll, NY.

Bowh Si, O.B., 2008, 'Mission as transformation: An exploration between the relationship of mission and development', International Review of Mission 97(384/385), 91-102.

Bragg, W.G., 1984, 'Beyond development to transformation', International Review of Missions 73(290), 153-165. https://doi.org/10.1111/j.1758-6631.1984.tb03262.x
Buys, P.J., 2013, 'A missional response to poverty and social injustice', in S.T. Logan, Jr. (ed.), Reformed means missional: Following Jesus into the world, pp. 67-96, New Growth Press, Greensboro, NC.

Corbett, S. \& Fikkert, B., 2012 [2009], When helping hurts: How to alleviate poverty without hurting the poor... and yourself, Moody Publishers, Chicago, IL.

Goheen, M., 2005, 'A critical examination of David Bosch's missional reading of Luke', in G. Bartholomew, J.B. Green \& A.C. Thiselton (eds.), Reading Luke: Interpretation, reflection, formation, pp. 229-264, Zondervan, Grand Rapids, MI.

Grigg, V., 1997 [1992], 'Church of the poor', in R.S. Greenway (ed.), Discipling the city: A comprehensive approach to urban mission, pp. 159-170, Baker Book House, Grand Rapids, MI.

Keenan, J., 2015, 'The Blood Cries Out', viewed 1 August 2017, from http:// foreignpolicy.com/2015/03/27/the-blood-cries-out-burundi-land-conflict/

Lygunda Li-M, F. \& Van Aarde, T.A., 2017, 'A fruitful missional exegesis for a missional hermeneutic and missiology', In die Skriflig 51(1), a2235. https://doi.org/10.4102/ ids.v51i1.2235

Ma, W., 2007, 'When the poor are fired up: The role of pneumatology in Pentecostal Charismatic mission', Transformation 24(1), 28-34. https://doi.org/10.1177/02 6537880702400105

Mbazumutima, T., 2007, 'The role of the Anglican Church in ministry to Burundian refugees in Tanzania with particular reference to the notions of hope and homeland', MA thesis, UNISA, Pretoria.

Motyer, A., 2011, Isaiah by the day: A new devotional translation, Christian Focus Publications, Ross-shire, Scotland, UK.

Mouw, R.J., 2011, 'Elected for a global mission: The call to the broader reformed agenda', in S.J. Roels (ed.), Reformed mission in an age of world Christianity: Ideas for the 21st century, pp. 15-25, Calvin Press, Grand Rapids, MI.

Myers, L.B., 1999, Walking with the poor: Principles and practices of transformational development, Orbis Books, Maryknoll, NY.

Nothwehr, D.M., 2010, 'Defining "racisms": Understanding our globalized, terrorized ecologically threatened world', in O.U. Kalu, P. Vethanayagamony \& E.K-F. Chia ecologically threatened world, in O.U. Kalu, P. Vethanayagamony \& E.K-F. Chia
(eds.), Mission after Christendom: Emergent themes in contemporary mission, (eds.), Mission after Christendom: Emergent themes in
pp. 115-127, Westminster John Knox Press, Louisville, KY.

Nyerere, J., 1974, Freedom and development. Uhuruna Maendeleo: A selection from writings and speeches 1968-1973, Oxford University Press, Dar es Salaam.

Oliver, S., 2010, 'Local Church: God's vehicle for empowering the poor', in N. Ring (ed.), Vision \& values, pp. 1-64, Newfrontiers, Chardon Villas, Hove.

Padilla, C.R., 2012, 'Global partnership and integral mission', in J. Corrie \& C. Ross (eds.), Mission in context: Explorations by J. Andrew Kirk, pp. 47-59, Routledge, Abingdon.

Poorta, J.L., 2010, 'Church and society: A Pentecostal perspective from the southern hemisphere', in W. Ma, V-M. Kärkkäinene \& J.K. Asomoah-Gyadu (eds.) Pentecostal mission and global Christianity, pp. 292-300, Regnum Books International, Oxford, UK. (Regnum Edinburg Centenary Series, 20).

Ring, N.D., 2011, The poor deserve the best: A manual for good practice, Newfrontiers, Claredon Villas, Hove.

Roy, B. \& Hartigen, J., 2008, 'Empowering the rural poor to empower themselves: The barefoot approach', Innovations 3(2), 67-93. https://doi.org/10.1162/ itgg.2008.3.2.67

Schreiter, R., 2010, 'Mission from the ground up: Emergent themes in contemporary mission', in O.U. Kalu, P. Vethanayagamony \& E.K-F. Chia (eds.), Mission after Christendom: Emergent themes in contemporary mission, pp. 12-24, Westminster John Knox Press, Louisville, KY.

Sunquist, S.W., 2013, Understanding Christian mission, Baker Academic, Grand Rapids, MI.

Van Aarde, T.A., 2015, 'The use of oikonomia in a missional reading of Luke-Acts', In die Skriflig 49(1), Art. \#2003, 9 pages. https://doi.org/10.4102/ids.v49i1.2003

Virgo, T.J., 2001, No well-worn paths - one man's journey: Restoring the church to Christ's original intention, Kingsway Publications, Eastbourne, UK.

Virgo, T.J., 2011, The spirit-filled church: Finding your place in God's purpose, Monarch Books, Oxford, UK.

Yong, A., 2010. 'Many tongues, many practices: Pentecost and theology of mission at 2010, in O.U. Kalu, P. Vethanayagamony \& E.K-F. Chia (eds.), Mission after Christendom: Emergent themes in contemporary mission, pp. 43-58, Westminster John Knox Press, Louisville, KY. 